\title{
Energy supplementation and herbage allowance effects on daily intake in lactating mares ${ }^{1}$
}

\author{
C. Collas, $* \dagger+$ B. Dumont, $\uparrow+$ R. Delagarde, $\S \#$ W. Martin-Rosset, $\uparrow+$ and G. Fleurance ${ }^{*}+\$^{2}$ \\ *IFCE, Direction des Connaissances et de l'Innovation, Terrefort, BP207, 49411 Saumur, France; \\ $\dagger$ INRA, UMR1213 Herbivores, Theix, 63122 Saint-Genès-Champanelle, France; †VetAgro Sup, UMR1213 \\ Herbivores, BP35, 89 avenue de l'Europe, 63370 Lempdes, France; §INRA, UMR1348 Physiologie, Environnement \\ et Génétique pour l'Animal et les Systèmes d'Elevage, 35590 Saint-Gilles, France; and \#Agrocampus Ouest, \\ UMR1348 Physiologie, Environnement et Génétique pour l'Animal et les Systèmes d'Elevage, 35000 Rennes, France
}

\begin{abstract}
Little is known about how to manage grazing horses, including the thresholds under which energy supplementation is required. Here we investigated the effects of daily herbage allowance (DHA) and energy supplementation (ES) on daily herbage intake in lactating mares of light breeds grazing high-quality regrowth during summer. Three contrasting DHA, low (LOW), medium (MED), and high (HIGH), that is, 35.0, 52.5, and $70.0 \mathrm{~g} \mathrm{DM} \cdot \mathrm{kg} \mathrm{BW}^{-1} \cdot \mathrm{d}^{-1}$, respectively, were obtained by adjusting pasture strip width. Eighteen Anglo-Arab and French Saddle lactating mares were either supplemented with $2.6 \mathrm{~kg}$ DM barley/d (SUP group; $n=9$ ) or left nonsupplemented (NSUP group; $n=9$ ) throughout the experiment. For 3 successive 2-wk periods, 3 groups of SUP mares $(n=3)$ and 3 groups of NSUP mares $(n=3)$ grazed each DHA according to a $3 \times 3$ Latin square design. Pregrazing sward surface height (SSH) was similar between treatments $(26.6 \mathrm{~cm})$, but postgrazing $\mathrm{SSH}$ differed significantly between each DHA (2.9, 4.4, and $5.7 \mathrm{~cm}$ for LOW, MED, and HIGH, respectively;
\end{abstract}

$P<0.001)$. Herbage DMI (HDMI) increased linearly from 18.5 to $23.4 \mathrm{~g} \mathrm{DM} \cdot \mathrm{kg} \mathrm{BW}^{-1} \cdot \mathrm{d}^{-1}$ with increasing DHA (i.e., $0.13 \mathrm{~kg}$ DM eaten $/ \mathrm{kg}$ DM of herbage offered; $P<0.001)$ independently of ES and with no significant ES $\times$ DHA interaction. This increase in HDMI resulted from an increase in grazing time between LOW (961 $\mathrm{min} / \mathrm{d}$ ) and MED and HIGH $(1,021 \mathrm{~min} / \mathrm{d} ; P<0.01)$ and from an increase in intake rate between LOW and MED (11.8 g DM/min) and HIGH (13.6 g DM/min; $P<0.01)$. Total digestible DMI (TDDMI) and NE intake (NEI) increased linearly from 12.3 to $15.2 \mathrm{~g} \mathrm{DM} \cdot \mathrm{kg} \mathrm{BW}^{-1} \cdot \mathrm{d}^{-1}$ and from 136.6 to $165.8 \mathrm{~kJ} \cdot \mathrm{kg} \mathrm{BW}^{-1} \cdot \mathrm{d}^{-1}$ with increasing DHA $(P<0.001)$, respectively. Total digestible DMI and NEI were significantly lower for NSUP than for SUP mares: 12.5 vs. $14.9 \mathrm{~g} \mathrm{DM} \cdot \mathrm{kg} \mathrm{BW}^{-1} \cdot \mathrm{d}^{-1}(P<0.01)$ and 134.6 vs. $166.5 \mathrm{~kJ} \cdot \mathrm{kg} \mathrm{BW}^{-1} \cdot \mathrm{d}^{-1}(P<0.001)$, respectively. Whereas SUP mares always met their energy requirements, NSUP mares no longer met theirs when DHA fell below $66 \mathrm{~g} \mathrm{DM} \cdot \mathrm{kg} \mathrm{BW}^{-1} \cdot \mathrm{d}^{-1}$ (i.e., $39 \mathrm{~kg} \mathrm{DM} \cdot \mathrm{mare}^{-1} \cdot \mathrm{d}^{-1}$ ).

Key words: concentrate, grazing, horse, nutritional requirements, sward availability

(C) 2015 American Society of Animal Science. All rights reserved.

J. Anim. Sci. 2015.93:2520-2529 doi:10.2527/jas2014-8447

\footnotetext{
${ }^{1} \mathrm{The} \mathrm{PhD}$ thesis of Claire Collas is funded by the French Horse and Riding Institute (IFCE) and the Animal Physiology and Livestock Farming System (Phase) division of INRA. We are grateful to the staff of the experimental farm of the IFCE for their technical assistance: Laurence Wimel, Patrice Dupuy, Joseph Bellonie, Ludivine Collon, Jacques Boulanger, Claude Larry, Cédric Dubois, and Patrick Paucard. We also thank Frédéric Anglard and Francis Decuq from INRA UMR1213 and students Nissirlany Cardoso Leal and Hélène Macé.

${ }^{2}$ Corresponding author: geraldine.fleurance@clermont.inra.fr Received August 27, 2014.

Accepted March 4, 2015.
}

\section{INTRODUCTION}

Grazed pastures are known as the cheapest source of nutrients for domestic herbivores if accurately managed (e.g., horses [Micol and Martin-Rosset, 1995] and dairy cows [Peyraud and Delaby, 2001]). Under strip or rotational grazing, DMI and animal performance are primarily controlled by daily herbage allowance (DHA; Wales et al., 1998; Pérez-Prieto and Delagarde, 2013). In ruminants, the relationship is curvilinear, 
with herbage intake increasing at a declining rate with increasing DHA (Dalley et al., 1999; Pérez-Prieto and Delagarde, 2013). Under low herbage allowance, concentrate supplementation increases total digestible DMI and performance (Delaby et al., 2001), whereas the response is low at high herbage allowance due to substitution between herbage and concentrate (Stockdale, 2000; Doyle et al., 2005). In spite of the increasing numbers of light horses in the last 30 to $40 \mathrm{yr}$ (American Horse Council, 2005; European Horse Network, 2010), little is known about how to feed them at pasture (but see Mésochina et al. [2000], Grace et al. [2002a], and Edouard et al. [2009, 2010] for growing horses). Lactating mares are, therefore, commonly supplemented with concentrate feed at pasture to ensure their performance. Collas et al. (2014), however, observed that under unlimited herbage conditions, the adaptive capacities of mares of light breeds enabled them to meet their requirements between the first and the fifth month of lactation and to produce foals with a satisfactory growth and conformation while relying on only herbage. In the present study, we set out to determine the herbage allowance threshold under which energy supplementation (ES) is required to feed lactating mares of light breeds on high-quality regrowth.

\section{MATERIALS AND METHODS}

The experiment was conducted in accordance to the national legislation on animal care (Certificate of Authorization to Experiment on Living Animals delivered by the Regional Ethic Committee for Animal Experimentation of Limousin, number 10-2013-10, Ministry of Agriculture, Food and Forestry, Limoges, France).

\section{Treatments and Experimental Design}

The experiment was conducted from 22 June to 2 August 2013 at the experimental farm of the French Horse and Riding Institute (IFCE) in Chamberet, France $\left(01^{\circ} 43^{\prime} 14^{\prime \prime}\right.$ E, 45 $35^{\prime} 03^{\prime \prime} \mathrm{N}$, and $440 \mathrm{~m}$ altitude). We used 18 lactating mares of light breeds either supplemented with $2.6 \mathrm{~kg} \mathrm{DM}$ barley/d (SUP; $n=9)$ or left nonsupplemented (NSUP; $n=9$ ). Supplemented and NSUP mares were divided into 3 groups of 3 mares and tested in a Latin square design with 3 levels of DHA measured at ground level: low (LOW), medium (MED) and high (HIGH), that is., 35.0, 52.5, and $70.0 \mathrm{~g} \mathrm{DM} \cdot \mathrm{kg}$ $\mathrm{BW}^{-1} \cdot \mathrm{d}^{-1}$, respectively. Expecting a voluntary herbage intake of $25 \mathrm{~g} \mathrm{DM} \cdot \mathrm{kg} \mathrm{BW}^{-1} \cdot \mathrm{d}^{-1}$ for NSUP lactating mares (i.e., mean value measured for NSUP lactating mares grazing the same pasture the previous summer; Collas et al., 2014), the high level of DHA (i.e., nonlimiting DHA) was chosen to be 2.5 to 3 times higher according to references obtained in dairy cows (Delagarde et al., 2011). Medium and low DHA were arbitrary chosen to offer three-fourths and half of the high DHA as a gradient. Each measurement period lasted 2 wk: Period 1 from 22 June to 5 July, Period 2 from 6 July to 19 July, and Period 3 from 20 July to 2 August. Mean daily precipitation (SE) was $1.1(0.5), 0.7(0.7)$, and $8.2 \mathrm{~mm} / \mathrm{d}$ (0.7) for periods 1,2 , and 3, respectively. Highs and lows for temperature were $20.0 \pm 1.1$ and $10.4 \pm 0.7^{\circ} \mathrm{C}$ for period $1,29.1 \pm 0.2$ and $15.5 \pm 0.3^{\circ} \mathrm{C}$ for period 2 , and $29.6 \pm 0.9$ and $15.1 \pm 0.6^{\circ} \mathrm{C}$ for period 3 , respectively.

\section{Animals}

Throughout the entire pregnancy, the 18 mares (Anglo-Arab and French Saddle breeds; 5-23 yr old) were collectively fed, according to their mean requirements (INRA, 2015), a diet composed of $43 \%$ grass hay (DM, $856 \mathrm{~g} / \mathrm{kg}$ DM; CP, $79 \mathrm{~g} / \mathrm{kg} \mathrm{DM}$; and crude fiber $[\mathbf{C F}], 361 \mathrm{~g} / \mathrm{kg} \mathrm{DM}$; experimental farm of the IFCE, Chamberet, France), 41\% haylage (DM, $614 \mathrm{~g} / \mathrm{kg}$; CP, $60 \mathrm{~g} / \mathrm{kg} \mathrm{DM}$; and CF, $364 \mathrm{~g} / \mathrm{kg} \mathrm{DM}$; experimental farm of the IFCE, Chamberet, France), and 16\% concentrate $(61.5 \%$ barley and $35 \%$ soybean meal [Agricentre Dumas, Espartignac, France] and 3.5\% minerals and vitamins [Chauveau Nutrition, Cholet, France]). As voluntary intake is affected by the mare's body condition at foaling (Doreau et al., 1993), the objective was that all mares achieved an optimal BCS of 3 at the start of the experiment, using the INRA scoring scale ranging from 0 (emaciated) to 5 (obese; Martin-Rosset et al., 2008). This optimal BCS corresponds to a BCS of 5 according to the NRC system (Henneke et al., 1983). To estimate the intake capacity of each mare, initial intake measurements were made in March indoors, with grass hay offered ad libitum for $8 \mathrm{~d}$ after 6 adaptation days. Intake capacity is defined as the amount of food that a horse should consume to meet its energy requirements and that is permitted by its digestive volume (INRA, 2015). In April, all the mares were treated against gastrointestinal parasites with ivermectin (Eqvalan; Merial, Lyon, France). After foaling, mares were split into 2 groups (SUP and NSUP) balanced for mare intake capacity $\left(23.7 \pm 1.4 \mathrm{~g} \mathrm{DM} \cdot \mathrm{kgBW}^{-1} \cdot \mathrm{d}^{-1}\right.$ for SUP and $24.1 \pm 1.8 \mathrm{~g} \mathrm{DM} \cdot \mathrm{kgBW}^{-1} \cdot \mathrm{d}^{-1}$ for NSUP), foaling date (14 April to 31 May for SUP [i.e., $47.2 \pm 4.6$ lactating days at the start of the experiment] and 26 April to 9 June for NSUP: [i.e., $40.3 \pm 5.7$ lactating days at the start of the experiment]), BCS (3.2 \pm 0.2 for SUP and $3.1 \pm 0.2$ for NSUP [i.e., BCS between 5 and 6 according to Henneke et al., 1983]), BW at foaling (547.2 \pm $14.4 \mathrm{~kg}$ for SUP and $538.0 \pm 10.4 \mathrm{~kg}$ for NSUP), height at withers $(163.3 \pm 1.3 \mathrm{~cm}$ for SUP and $161.9 \pm 0.9 \mathrm{~cm}$ for NSUP), and age ( $8.6 \pm 1.9 \mathrm{yr}$ old for SUP and $6.8 \pm$ $0.9 \mathrm{yr}$ old for NSUP). The 18 mares were, therefore, at 
2, 2.5, and 3 mo of lactation, on average, during the first, second, and third experimental periods, respectively.

From 22 June to 2 August, SUP mares received a daily supplement of $2.6 \mathrm{~kg}$ DM of rolled barley (Table 1; Agricentre Dumas) at pasture, which accounted for $63 \%$ of energy requirements for their mean stage of lactation (i.e., $2.5 \mathrm{mo}$; INRA, 2015; i.e., $67 \%$ according to the NRC [2007] feed evaluation system). During the second week of each period, NSUP mares were fed $260 \mathrm{~g}$ DM of rolled barley daily; the 18 mares ate $100 \mathrm{~g}$ of small colored plastic balls (1 color per mare) mixed with the barley to individualize feces at pasture (see Intake Measurements). All the mares were accustomed to being individually fed with barley at pasture by the week before measurements began. They were weighed at the same time of day on the first day of each period (for SUP, $589.3 \pm 12.0,593.5 \pm 13.6$, and $588.8 \pm$ $12.0 \mathrm{~kg}$ for LOW, MED, and HIGH, respectively, and for NSUP, $584.5 \pm 13.2,589.2 \pm 12.9$, and $576.1 \pm 10.1$ $\mathrm{kg}$ for LOW, MED, and HIGH, respectively).

\section{Pasture Composition and Grazing Management}

Mares and their foals were strip grazed on a fertile permanent pasture ( 25 species; $60 \%$ grass cover). The most abundant species were rough bluegrass ( $\mathrm{Poa}$ trivialis), perennial ryegrass (Lolium perenne), white clover (Trifolium repens), and dandelion (Taraxacum officinale). The pasture was divided into 3 paddocks. One paddock was used for each period and was, therefore, mown beforehand at a different date to ensure identical vegetation stage for measurements. Each paddock was divided into 6 subpaddocks, and each was used by 3 mares and their foals for 1 of the treatments (SUP-LOW, NSUP-LOW, SUP-MED, NSUPMED, SUP-HIGH, and NSUP-HIGH).

As foals graze after 2 mo of age (INRA, 2015), it was necessary to estimate the amount of herbage they would consume during the second and the third periods so that strip width could be slightly increased. We calculated that foals consumed $5 \mathrm{~g} \mathrm{DM} \cdot \mathrm{kg} \mathrm{BW}^{-1} \cdot \mathrm{d}^{-1}$ during the second period (mean $\mathrm{BW}=135 \mathrm{~kg}$ ) and $6 \mathrm{~g}$ $\mathrm{DM} \cdot \mathrm{kg} \mathrm{BW}{ }^{-1} \cdot \mathrm{d}^{-1}$ during the third period (mean $\mathrm{BW}=$ $145 \mathrm{~kg}$ ) by considering foal daily gain and requirements, mares' milk yield, and sward nutritive value (TrillaudGeyl et al., 1990; INRA, 2015).

The strips of pasture were allocated for $2 \mathrm{~d}$ of grazing by moving electric fences. Mares and foals were moved into a new strip of fresh herbage every 2 mornings at $0915 \mathrm{~h}$. Access by mares and foals to the previously grazed strip was prevented by back fencing. This management enabled us to offer the animals identical swards and DHA during the 2-wk period by adjusting strip width to herbage mass. Strip width to be
Table 1. Chemical composition and nutritive value of the supplement (barley)

\begin{tabular}{lc}
\hline \hline Item $^{1,2}$ & Barley \\
\hline $\mathrm{DM}, \mathrm{g} / \mathrm{kg}$ & 867 \\
Chemical composition, g/kg DM & \\
OM & 974 \\
$\mathrm{CP}$ & 116 \\
$\mathrm{CF}$ & 52 \\
$\mathrm{NDF}$ & 216 \\
$\mathrm{ADF}$ & 63 \\
Nutritive value & \\
DM digestibility, g/kg DM & 81 \\
$\mathrm{NE}, \mathrm{MJ} / \mathrm{kg}$ DM & 10.7 \\
$\mathrm{HDCP}, \mathrm{g} / \mathrm{kg}$ DM & 82 \\
\hline${ }^{1} \mathrm{CF}=$ crude fiber; HDCP = horse digestible CP. & \\
${ }^{2}$ From INRA feed tables (INRA, 2015). &
\end{tabular}

offered for $2 \mathrm{~d}$ was determined using the mean sward surface height (SSH) measured every $2 \mathrm{~d}$ in the next area to be grazed and a $\mathrm{SSH}$-herbage mass regression updated once weekly (see Vegetation Characteristics).

\section{Vegetation Characteristics}

Sward surface height and herbage mass were simultaneously measured once weekly in twelve 0.49 $\mathrm{m}^{2}$ (70 by $70 \mathrm{~cm}$ ) quadrats (i.e., 2 per subpaddock), randomly selected among areas of short (11 to $19 \mathrm{~cm}$ on average according to period), medium (14 to $24 \mathrm{~cm}$ on average according to period), and tall (16 to $30 \mathrm{~cm}$ on average according to period) $\mathrm{SSH}$, on the next area to be grazed. Twelve SSH measurements were made before herbage cut in each quadrat by recording the first contact of a stick with the undisturbed sward surface. Herbage cut at ground level with hand shears was weighed and then divided into 2 samples. One sample per quadrat was dried for $24 \mathrm{~h}$ at $103^{\circ} \mathrm{C}$ to determine herbage DM content and then calculate herbage mass and establish the $\mathrm{SSH}-$ herbage mass regression. The other sample was dried for $72 \mathrm{~h}$ at $60^{\circ} \mathrm{C}$ and analyzed for CP (Dumas method NF V18-120; AFNOR, 1997), cellulose (CF; Weende method NF V03-040; AFNOR, 1993), and NDF and ADF (Goering and Van Soest, 1970). Thirty pregrazing SSH measurements were made in each subpaddock before the animals entered so that strip width could be determined using the SSHherbage mass regression according to the targeted low, medium, and high DHA. Postgrazing SSH was also measured every $2 \mathrm{~d}$ with 15 random points per strip.

\section{Daily Intake and Energy and Protein Balances}

Daily herbage DMI (HDMI) was measured for each mare during the last $4 \mathrm{~d}$ of each period as 
Table 2. Daily offered area and characteristics of herbage on offer for grazing according to energy supplementation (ES; supplemented with $2.6 \mathrm{~kg}$ DM barley/d [SUP] and nonsupplemented [NSUP]) level and daily herbage allowance (DHA; low [LOW], medium [MED], and high [HIGH])

\begin{tabular}{|c|c|c|c|c|c|c|c|c|c|c|c|c|}
\hline \multirow[b]{2}{*}{ Item $^{1}$} & \multicolumn{3}{|c|}{ SUP } & \multicolumn{3}{|c|}{ NSUP } & \multirow[b]{2}{*}{$\mathrm{RMSE}^{2}$} & \multicolumn{5}{|c|}{$P$-value } \\
\hline & LOW & MED & HIGH & LOW & MED & HIGH & & ES & DHA & $\mathrm{ES} \times \mathrm{DHA}$ & $\operatorname{Lin}^{3}$ & Quad $^{3}$ \\
\hline DHA, g DM $\cdot \mathrm{kg} \mathrm{BW}^{-1} \cdot \mathrm{d}^{-1}$ & 35.0 & 52.5 & 70.0 & 35.0 & 52.5 & 70.0 & - & - & - & - & - & - \\
\hline DHA, kg DM.mare ${ }^{-1} \cdot \mathrm{d}^{-1}$ & 20.6 & 30.9 & 41.2 & 20.6 & 30.9 & 41.2 & - & - & - & - & - & - \\
\hline DOA, $\mathrm{m}^{2} \cdot \mathrm{mare}^{-1} \cdot \mathrm{d}^{-1}$ & 59.2 & 90.2 & 122.3 & 65.1 & 86.1 & 121.2 & 19.0 & 0.972 & $<0.001$ & 0.438 & $<0.001$ & 0.477 \\
\hline \multicolumn{13}{|l|}{ Sward surface height, $\mathrm{cm}$} \\
\hline Pregrazing & 27.6 & 25.9 & 28.2 & 23.7 & 27.0 & 27.3 & 6.7 & 0.295 & 0.377 & 0.225 & 0.560 & 0.460 \\
\hline Postgrazing & 2.8 & 4.6 & 5.8 & 3.1 & 4.1 & 5.6 & 1.5 & 0.699 & $<0.001$ & 0.422 & $<0.001$ & $<0.001$ \\
\hline Pregrazing HM, t DM/ha & 3.86 & 3.62 & 3.86 & 3.38 & 3.82 & 3.86 & 0.70 & 0.448 & 0.281 & 0.077 & 0.334 & 0.933 \\
\hline $\mathrm{DM}, \mathrm{g} / \mathrm{kg}$ & 236 & 259 & 249 & 264 & 255 & 232 & 0.05 & 0.865 & 0.687 & 0.459 & 0.792 & 0.607 \\
\hline \multicolumn{13}{|l|}{ Sward quality, g/kg DM } \\
\hline $\mathrm{OM}$ & 899 & 897 & 876 & 889 & 908 & 896 & 0.04 & 0.368 & 0.193 & 0.245 & 0.430 & 0.123 \\
\hline $\mathrm{CP}$ & 144 & 156 & 163 & 145 & 147 & 154 & 0.03 & 0.443 & 0.237 & 0.837 & 0.176 & 0.960 \\
\hline $\mathrm{CF}$ & 268 & 245 & 230 & 248 & 256 & 265 & 0.05 & 0.509 & 0.800 & 0.274 & 0.505 & 0.908 \\
\hline $\mathrm{NDF}$ & 571 & 540 & 545 & 555 & 577 & 566 & 0.04 & 0.340 & 0.911 & 0.289 & 0.670 & 0.939 \\
\hline $\mathrm{ADF}$ & 321 & 298 & 301 & 311 & 324 & 319 & 0.03 & 0.221 & 0.841 & 0.235 & 0.617 & 0.876 \\
\hline
\end{tabular}

${ }^{1} \mathrm{DOA}=$ daily offered area; $\mathrm{HM}=$ herbage mass $; \mathrm{CF}=$ crude fiber.

${ }^{2} \mathrm{RMSE}=$ root mean square error.

${ }^{3}$ Lin = linearity of DHA effect; Quad = quadricity of DHA effect.

$$
\mathrm{HDMI}=\mathrm{FO} /(1-\mathrm{HDMD}),
$$

in which FO is the dry weight of fecal output over $24 \mathrm{~h}$ attributable to herbage and HDMD is the DM digestibility of ingested herbage expressed as a decimal value.

In horses, feces are dry enough to collect them without losses or contamination. Fecal output was, therefore, determined by total fecal collection, which is the reference method (Penning, 2004) previously used in a large number of horse studies (e.g., Duncan, 1992; Mésochina et al., 2000; Grace et al., 2002a,b; Edouard et al., 2009, 2010; Collas et al., 2014). Feces were collected once a day over 4 successive days after the paddock had been cleaned of feces. Individualization of feces was made possible identifying the small plastic balls of different colors ( 1 color per mare) that were mixed with the barley (see Animals). Total daily fecal outputs were individually weighed, and a subsample was dried for $72 \mathrm{~h}$ at $80^{\circ} \mathrm{C}$ to determine fecal DM and CP contents. Fecal DM output attributable to herbage was then calculated by subtracting the indigestible DM attributable to barley (INRA, 2015; Table 1) from the total fecal DM output (Delagarde et al., 1999; Collas et al., 2014).

Dry matter digestibility of ingested herbage was estimated from fecal CP content attributable to herbage according to the equation of Mésochina et al. (1998):

$$
\mathrm{HDMD}=0.734-(17.872 / \text { fecal CP content }),
$$

in which fecal $\mathrm{CP}$ content is expressed in grams per kilogram DM.
Mésochina et al. (1998) stressed that the conditions of applicability of this equation are for herbage $\mathrm{CP}$ contents greater than $70 \mathrm{~g} / \mathrm{kg} \mathrm{DM}$, which limits N recycling by horses. This was always the case in the present experiment (Table 2). The fecal CP content attributable to herbage was calculated by dividing the amount of fecal CP attributable to herbage by the fecal DM output attributable to herbage. The amount of fecal $\mathrm{CP}$ attributable to herbage was calculated by subtracting the amount of fecal CP attributable to barley from the total CP amount excreted from feces (Delagarde et al., 1999; Collas et al., 2014). The amount of fecal CP attributable to barley was calculated from the CP content of barley and from the apparent CP digestibility of barley (INRA, 2015; Table 1).

Total DMI (TDMI) was calculated as the sum of HDMI and barley DMI (BDMI) recorded daily when mares were supplemented. Daily total digestible DMI (TDDMI) was then calculated as the sum of herbage digestible DMI and barley digestible DMI:

$$
\mathrm{TDDMI}=\mathrm{HDMI} \times \mathrm{HDMD}+\mathrm{BDMI} \times \mathrm{BDMD},
$$

in which BDMD is the DM digestibility of barley (INRA, 2015; Table 1).

Net energy intake was estimated from herbage and barley NE contents according to the INRA (INRA, 2015) feed evaluation system:

herbage NE content $=[(0.825-0.0011 \times \mathrm{CF}+$ $0.0006 \times \mathrm{CP}) \times 2,250] \times 4.18$, 
in which herbage NE content is expressed in kilojoules per kilogram DM, CF and $\mathrm{CP}$ are expressed in grams per kilogram DM, and 2,250 is the NE content (kcal) of $1 \mathrm{~kg}$ of fresh standard barley (INRA, 2015).

Horse digestible CP (HDCP) intake was estimated from herbage and barley digestible CP (DCP) contents according to the INRA (INRA, 2015) feed evaluation system:

$$
\text { herbage DCP content }=(-74.52+0.9568 \times
$$$$
\mathrm{CP}+0.1167 \times \mathrm{CF}) \times 0.9 \text {, }
$$

in which herbage DCP content is expressed as grams DCP per kilogram DM and CP and CF are expressed in grams per kilogram DM.

Individual consumptions of energy and protein were then expressed in relation to the mares' requirements at each period. Mares' requirements were estimated using their reference BW at foaling, their stage of lactation, and INRA nutrient requirements tabulated per BW classes (INRA, 2015).

Individual energy and protein intakes were also calculated according to the NRC (2007) feed evaluation system and were expressed in relation to the mares' requirements using tabulated NRC requirements and the same procedure as previously described.

Digestible energy intake was estimated from herbage and barley DE contents according to the NRC (2007) feed evaluation system:

herbage DE content $=(4.22-0.11 \times \mathrm{ADF}+$ $\left.0.0332 \times \mathrm{CP}+0.00112 \times \mathrm{ADF}^{2}\right) \times 4.18 \times 10^{3}$ and

barley $\mathrm{DE}$ content $=(4.07-0.055 \times \mathrm{ADF}) \times$ $4.18 \times 10^{3}$,

in which herbage DE content and barley DE content are expressed in kilojoules per kilogram DM and ADF and $\mathrm{CP}$ are expressed as a percentage of DM.

Crude protein intake was estimated from herbage and barley CP contents according to the NRC (2007) feed evaluation system.

\section{Grazing Behavior}

Daily grazing time of the mares was recorded over $48 \mathrm{~h}$ in the middle of the first week of each period using Ethosys collars (Greenway System GmbH, Frankfurt, Germany) to record head position and movements (1 recording every $5 \mathrm{~min}$; Scheibe et al., 1998). Animals were accustomed to wearing the collars by the week before measurements began. We also evaluated grazing time during the first $12 \mathrm{~h}$ (from 0915 to $2115 \mathrm{~h}$ ), after the animals entered a new strip, and during the last $12 \mathrm{~h}$ (from 2115 to $0915 \mathrm{~h}$ ), before they left it. Herbage intake rate was estimated by dividing daily herbage intake by daily grazing time.

\section{Statistical Analyses}

Data were analyzed using the PROC GLM procedure of SAS (SAS Inst. Inc., Cary, NC). Sward and grazing management data were analyzed in a model that included the effects of period, DHA, ES, and the ES $\times$ DHA interaction. Animal data were analyzed in a model that included the effects of period, DHA, ES, mare nested within ES (as mares were either supplemented or not for all the experiment), and the ES $\times$ DHA interaction. Effect of ES was tested separately using the mare effect as residual term. Orthogonal contrasts were used to test whether the DHA effect was linear or quadratic. Differences between DHA were investigated using the Tukey correction for multiple comparisons; the significance threshold was $P<0.05$.

\section{RESULTS}

\section{Vegetation Characteristics}

Pregrazing SSH $(26.6 \mathrm{~cm})$ and pregrazing herbage mass $(3.73 \mathrm{t} \mathrm{DM} / \mathrm{ha})$ were similar across all the treatments (Table 2). The 3 contrasting DHA chosen were obtained by linearly increasing the area offered daily (Table 2). Postgrazing SSH was not affected by ES and increased by $0.13 \mathrm{~cm} / \mathrm{kg}$ of dry herbage offered (linear and quadratic effects, $P<0.001$; Table 2). Herbage DM (249 g/kg), OM (895 g/kg DM), CP (151 g/kg DM), CF (252 g/kg DM), NDF (559 g/kg DM), and ADF (312 g/kg DM) contents were independent of ES and DHA levels (Table 2).

\section{Daily Intake and Energy and Protein Balances}

None of the intake variables were affected by ES $\times$ DHA (Table 3; Fig. 1), which means that the mares responded similarly to DHA variations whether supplemented or not. Fecal output attributable to herbage (FO), HDMD, HDMI, herbage digestible DMI (HDDMI), TDMI, and HDCP intake did not significantly differ between SUP and NSUP mares, despite a tendency for FO to be greater in NSUP mares and for TDMI to be greater in SUP mares (Table 3; Fig. 1). Mares ate all the barley offered during the experiment. Consequently, SUP mares achieved greater TDDMI (14.9 g digestible $\mathrm{DM} \cdot \mathrm{kg} \mathrm{BW}^{-1} \cdot \mathrm{d}^{-1}$ for SUP and $12.5 \mathrm{~g} \mathrm{DDM} \cdot \mathrm{kg} \mathrm{BW}^{-1} \cdot \mathrm{d}^{-1}$ for NSUP; $P<0.01)$ and NE intake (NEI; $166.5 \mathrm{~kJ} \cdot \mathrm{kg}$ $\mathrm{BW}^{-1} \cdot \mathrm{d}^{-1}$ for SUP and $134.6 \mathrm{~kJ} \cdot \mathrm{kg} \mathrm{BW}^{-1} \cdot \mathrm{d}^{-1}$ for NSUP; $P<0.001$ ) than NSUP mares (Table 3; Fig. 1). Dry matter digestibility of ingested herbage increased linearly 
Table 3. Mares' daily intake according to energy supplementation (ES; supplemented with $2.6 \mathrm{~kg}$ DM barley/d [SUP] and nonsupplemented [NSUP]) level and daily herbage allowance (DHA; low [LOW], medium [MED], and high $[\mathrm{HIGH}])$

\begin{tabular}{|c|c|c|c|c|c|c|c|c|c|c|c|c|}
\hline \multirow[b]{2}{*}{ Item $^{1}$} & \multicolumn{3}{|c|}{ SUP } & \multicolumn{3}{|c|}{ NSUP } & \multirow[b]{2}{*}{$\mathrm{RMSE}^{2}$} & \multicolumn{5}{|c|}{$P$-value } \\
\hline & LOW & MED & HIGH & LOW & MED & HIGH & & ES & DHA & $\mathrm{ES} \times \mathrm{DHA}$ & $\operatorname{Lin}^{3}$ & Quad $^{3}$ \\
\hline$\overline{\mathrm{FO}, \mathrm{g} \mathrm{DM} \cdot \mathrm{kg} \mathrm{BW}^{-1} \cdot \mathrm{d}^{-1}}$ & 7.8 & 8.4 & 9.7 & 8.5 & 9.8 & 10.7 & 0.6 & 0.064 & $<0.001$ & 0.635 & $<0.001$ & 0.669 \\
\hline HDMD, g/kg DM & 560 & 566 & 570 & 551 & 556 & 557 & 0.5 & 0.146 & $<0.05$ & 0.754 & $<0.01$ & 0.599 \\
\hline HDMI, g DM $\cdot \mathrm{kg} \mathrm{BW}^{-1} \cdot \mathrm{d}^{-1}$ & 17.9 & 19.2 & 22.5 & 19.0 & 22.0 & 24.3 & 2.4 & 0.148 & $<0.001$ & 0.590 & $<0.001$ & 0.655 \\
\hline HDMI, kg DM.mare ${ }^{-1} \cdot \mathrm{d}^{-1}$ & 10.6 & 11.4 & 13.2 & 11.1 & 12.9 & 14.0 & 1.4 & 0.241 & $<0.001$ & 0.568 & $<0.001$ & 0.976 \\
\hline HDDMI, g DDM $\cdot \mathrm{kg} \mathrm{BW}^{-1} \cdot \mathrm{d}^{-1}$ & 10.1 & 10.9 & 12.8 & 10.5 & 12.3 & 13.6 & 1.3 & 0.281 & $<0.001$ & 0.561 & $<0.001$ & 0.661 \\
\hline HDDMI, kg DM.mare ${ }^{-1} \cdot \mathrm{d}^{-1}$ & 5.9 & 6.5 & 7.5 & 6.1 & 7.2 & 7.8 & 0.8 & 0.390 & $<0.001$ & 0.543 & $<0.001$ & 0.945 \\
\hline TDMI, g DM $\cdot \mathrm{kg} \mathrm{BW}^{-1} \cdot \mathrm{d}^{-1}$ & 22.4 & 23.7 & 27.0 & 19.5 & 22.5 & 24.8 & 2.4 & 0.118 & $<0.001$ & 0.585 & $<0.001$ & 0.634 \\
\hline TDMI, $\mathrm{kg}$ DM$\cdot \mathrm{mare}^{-1} \cdot \mathrm{d}^{-1}$ & 13.2 & 14.1 & 15.8 & 11.4 & 13.2 & 14.2 & 1.4 & 0.083 & $<0.001$ & 0.568 & $<0.001$ & 0.976 \\
\hline TDDMI, g DDM $\cdot \mathrm{kg} \mathrm{BW}^{-1} \cdot \mathrm{d}^{-1}$ & 13.7 & 14.5 & 16.5 & 10.9 & 12.6 & 14.0 & 1.4 & $<0.01$ & $<0.001$ & 0.542 & $<0.001$ & 0.614 \\
\hline TDDMI, $\mathrm{kg}$ DM$\cdot \mathrm{mare}^{-1} \cdot \mathrm{d}^{-1}$ & 8.1 & 8.6 & 9.7 & 6.3 & 7.4 & 8.0 & 0.8 & $<0.01$ & $<0.001$ & 0.543 & $<0.01$ & 0.973 \\
\hline
\end{tabular}

${ }^{1} \mathrm{FO}=$ fecal output attributable to herbage; HDMD = DM digestibility of ingested herbage; HDMI = herbage DMI; HDDMI = herbage digestible DMI; $\mathrm{DDM}=$ digestible DM; TDMI $=$ total DMI; TDDMI $=$ total digestible DMI

${ }^{2} \mathrm{RMSE}=$ root mean square error.

${ }^{3}$ Lin = linearity of DHA effect; Quad = quadricity of DHA effect.

with increasing DHA and was significantly lower on LOW than on HIGH (556 vs. $564 \mathrm{~g} / \mathrm{kg} \mathrm{DM}$ ). Fecal output attributable to herbage $(8.2,9.1$, and $10.2 \mathrm{~g} \mathrm{DM} \cdot \mathrm{kg}$ $\mathrm{BW}^{-1} \cdot \mathrm{d}^{-1}$ for LOW, MED, and HIGH, respectively), HDMI $\left(18.4,20.6\right.$, and $23.4 \mathrm{~g} \mathrm{DM} \cdot \mathrm{kg} \mathrm{BW}^{-1} \cdot \mathrm{d}^{-1}$ for LOW, MED, and HIGH, respectively), HDDMI (10.3, 11.6, and $13.2 \mathrm{~g} \mathrm{DDM} \cdot \mathrm{kg} \mathrm{BW}^{-1} \cdot \mathrm{d}^{-1}$ for LOW, MED, and HIGH, respectively), TDMI (20.9, 23.1, and $25.9 \mathrm{~g}$ $\mathrm{DM} \cdot \mathrm{kg} \mathrm{BW}{ }^{-1} \cdot \mathrm{d}^{-1}$ for LOW, MED, and HIGH, respectively), TDDMI (12.3, 13.6, and $15.2 \mathrm{~g}$ DDM $\cdot \mathrm{kg}$ $\mathrm{BW}^{-1} \cdot \mathrm{d}^{-1}$ for LOW, MED, and $\mathrm{HIGH}$, respectively), NEI (136.6, 149.3, and $165.8 \mathrm{~kJ} \cdot \mathrm{kg} \mathrm{BW}^{-1} \cdot \mathrm{d}^{-1}$ for LOW, MED, and HIGH, respectively), and HDCP intake (1.9, 2.1, and $2.3 \mathrm{~g} \mathrm{HDCP} \cdot \mathrm{kg} \mathrm{BW}^{-1} \cdot \mathrm{d}^{-1}$ for LOW, MED, and HIGH, respectively) increased linearly with increasing DHA $(P<0.001)$, with significant differences between each DHA(Table 3; Fig. 1). Mares increased their HDMI and their TDMI by $0.13 \mathrm{~kg} \mathrm{DM} / \mathrm{kg}$ dry herbage offered $(P<0.001)$. Mares' consumption of energy and protein in relation to their requirements increased linearly with increasing DHA $(P<0.001)$, although no significant difference was observed for protein requirements between LOW and MED (Fig. 2). Supplemented mares met a higher proportion of both their energy $(P<0.001)$ and protein $(P=0.051)$ requirements than NSUP mares (Fig. $2)$. Supplemented mares always met their energy requirements, but NSUP mares fell short at the low and medium DHA (Fig. 2). All the mares met their protein requirements irrespective of DHA and ES (Fig. 2). The same conclusions were obtained when expressing our results according to the NRC system: SUP and NSUP mares increased their DE intakes with DHA (for SUP mares, $247.6 \pm 12.3,260.2 \pm 8.6$, and $293.0 \pm 14.4 \mathrm{~kJ} \cdot \mathrm{kg} \mathrm{BW}^{-}$ ${ }^{1} \cdot \mathrm{d}^{-1}$ for LOW, MED, and HIGH, respectively, and for
NSUP mares, $196.4 \pm 11.1,226.7 \pm 12.6$, and $249.4 \pm 9.8$ $\mathrm{kJ} \cdot \mathrm{kg} \mathrm{BW}^{-1} \cdot \mathrm{d}^{-1}$ for LOW, MED, and HIGH, respectively) but NSUP mares did not meet their energy requirements on low and medium DHA (for SUP mares, 104, 110 , and $123 \%$ for LOW, MED, and HIGH, respectively, and for NSUP mares, 82, 95, and 102\% for LOW, MED, and $\mathrm{HIGH}$, respectively). Consumption of protein (for SUP mares, $3.3 \pm 0.2,3.4 \pm 0.1$, and $3.9 \pm 0.2 \mathrm{~g} \mathrm{CP} \cdot \mathrm{kg}$ $\mathrm{BW}^{-1} \cdot \mathrm{d}^{-1}$ for LOW, MED, and HIGH, respectively, and for NSUP mares, $2.9 \pm 0.2,3.4 \pm 0.2$, and $3.7 \pm 0.2 \mathrm{~g}$ $\mathrm{CP} \cdot \mathrm{kg} \mathrm{BW}{ }^{-1} \cdot \mathrm{d}^{-1}$ for LOW, MED, and HIGH, respectively) always met the mares' requirements whatever the treatment (119 to $142 \%$ for SUP mares according to DHA and 106 to $133 \%$ for NSUP mares according to DHA).

\section{Grazing Behavior}

Mares' grazing behavior was affected by neither ES nor ES $\times$ DHA (Table 4). Both SUP and NSUP mares grazed significantly longer on medium and high than on low DHA $(1,021$ vs. $962 \mathrm{~min} / \mathrm{d} ; P<$ 0.01 ; Table 4 ). The lower daily grazing time spent by mares on LOW resulted from a significantly lower activity from 2115 to 0915 h (359 vs. 420 min; $P<$ 0.01; Table 4), with DHA mainly influencing grazing activity on the second day on a strip (Fig. 3). All the mares achieved a significantly greater herbage intake rate when DHA was highest than with MED and LOW (13.6 vs. $11.8 \mathrm{~g} \mathrm{DM} / \mathrm{min} ; P<0.01$; Table 4 ).

\section{DISCUSSION}

The aim of this experiment was to assess the effect of herbage allowance and ES on herbage intake by 

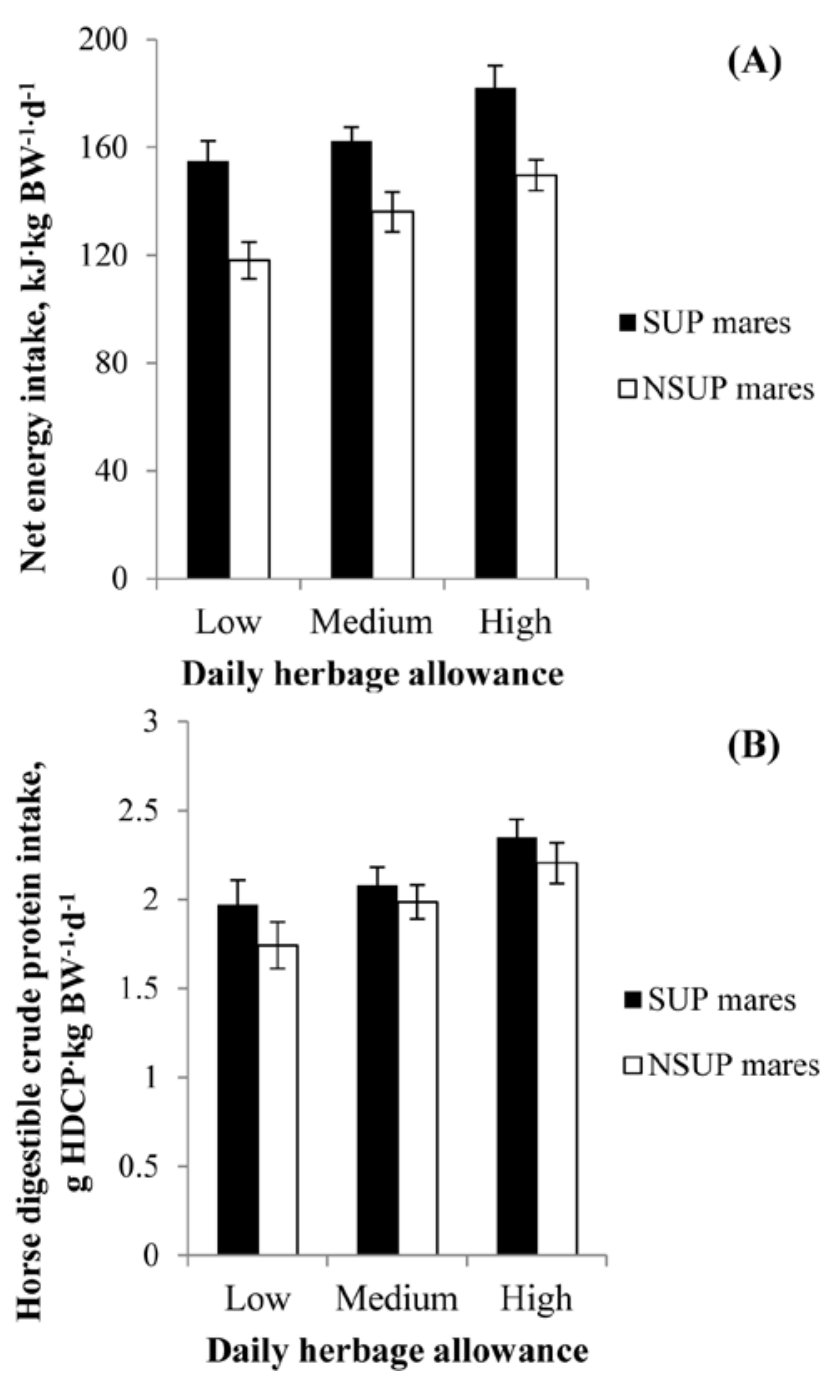

Figure 1. (A) Net energy intake according to energy supplementation (ES; $P<0.001$ ) and daily herbage allowance (DHA; $P<0.001$; mean \pm SE; ES $\times$ DHA interaction, $P>0.05$; linearity of DHA effect, $P<0.01$; and quadricity of DHA effect, $P>0.05$ ). (B) Horse digestible CP intake according to $\mathrm{ES}(P>0.05)$ and DHA $(P<0.001 ;$ mean \pm SE; ES $\times$ DHA interaction, $P>0.05$; linearity of DHA effect, $P<0.001$; and quadricity of DHA effect, $P>0.05$ ). SUP = supplemented with $2.6 \mathrm{~kg} \mathrm{DM}$ barley $/ \mathrm{d}$; NSUP $=$ nonsupplemented; HDCP $=$ horse digestible $\mathrm{CP}$.

lactating mares. Most of the work showing that these factors are major determinants of DMI, grazing time, and animal performance has, so far, been performed with ruminants (mainly dairy cows), and therefore, it is not known whether the same rules apply to horses.

\section{Daily Herbage Allowance}

The 3 DHA used in this experiment resulted in contrasting HDMI by lactating mares ranging from 77 to $98 \%$ of their intake capacity (i.e., intake measurements performed in March indoors, with grass hay offered ad libitum; see Materials and Methods). The effect of DHA on HDMI was linear, and we could calculate an increase of $0.13 \mathrm{~kg}$ DM eaten by mares $/ \mathrm{kg}$ DM of herbage offered at ground level. This value is close to that
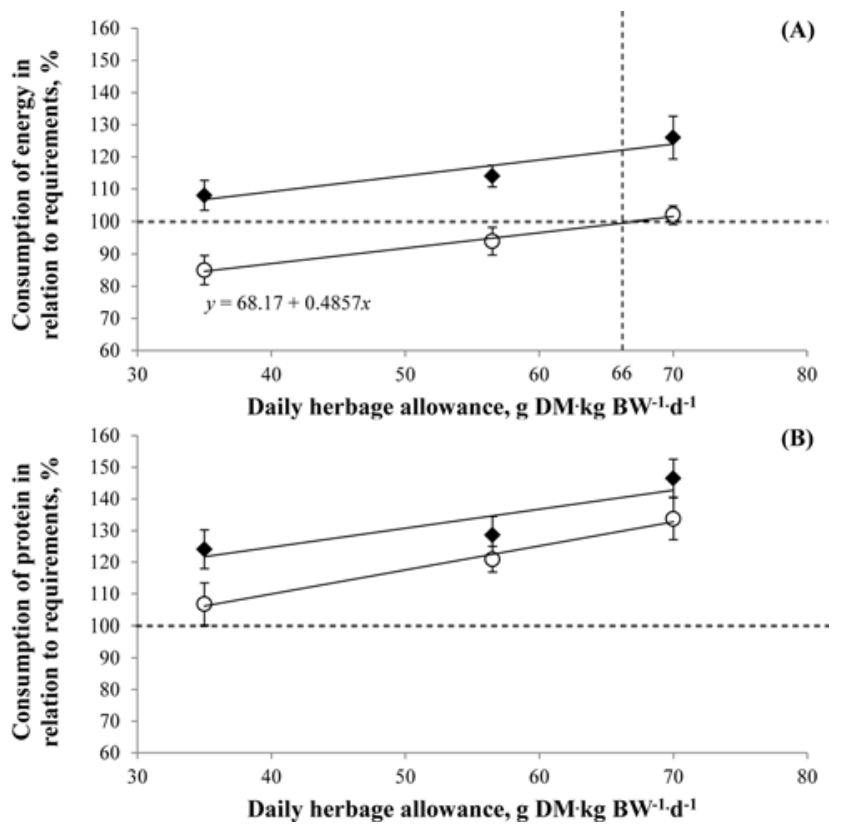

Figure 2. (A) Consumption of energy in relation to requirements according to energy supplementation (ES; - = supplemented with $2.6 \mathrm{~kg}$ $\mathrm{DM}$ barley/d [SUP] mares and $\mathrm{O}=$ nonsupplemented [NSUP] mares; $P<$ 0.001 ) and daily herbage allowance (DHA; $P<0.001$ ) using INRA (INRA, 2015 ) recommendations (ES $\times$ DHA interaction, $P>0.05$; linearity of DHA effect, $P<0.01$; and quadricity of DHA effect, $P>0.05$ ). From the linear effect of DHA on herbage DMI we estimate at $66 \mathrm{~g} \mathrm{DM} \cdot \mathrm{kg} \mathrm{BW}^{-1} \cdot \mathrm{d}^{-1}$ (i.e., $39 \mathrm{~kg} \mathrm{DM} \cdot \mathrm{mare}^{-1} \cdot \mathrm{d}^{-1}$ ) the DHA threshold under which ES is needed for lactating mares to meet their energy requirements on high-quality regrowth. (B) Consumption of protein in relation to requirements according to ES ( $\bullet=$ SUP mares and $O=$ NSUP mares; $P=0.051)$ and DHA $(P<0.001)$ using INRA (INRA, 2015) recommendations (ES $\times$ DHA interaction, $P>0.05$; linearity of DHA effect, $P<0.001$; and quadricity of DHA effect, $P>0.05$ ).

reported by Peyraud and Delagarde (2013) for dairy cows (i.e., $0.15 \mathrm{~kg} \mathrm{DM}$ eaten $/ \mathrm{kg} \mathrm{DM}$ of herbage offered) within the typical range of herbage allowance for dairy systems. Herbage intake by growing horses ( 1 and 2 yr old) was unaffected by DHA in the range of 130 to $200 \mathrm{~g} \mathrm{DM} \cdot \mathrm{kg} \mathrm{BW}^{-1} \cdot \mathrm{d}^{-1}$ (Mésochina et al., 2000), which suggests that herbage intake reaches a plateau for high DHA. No study on grazing horses has been reported with the same range of DHA as that tested in this experiment. Conversely, under low DHA conditions, mares grazed closer to the ground $(2.9 \mathrm{~cm}$ on LOW vs. $5.7 \mathrm{~cm}$ on HIGH) and probably ingested a greater proportion of fiber, which decreased herbage digestibility by $10 \mathrm{~g} / \mathrm{kg}$ DM from high to low DHA, that is, a $2 \%$ relative variation. However, the decrease in HDDMI observed between HIGH and LOW $(-22 \%)$ was mostly explained by a decrease in HDMI $(-21 \%)$, with regrowth quality remaining high $(15 \% \mathrm{DM}$ for $\mathrm{CP}$ and $56 \%$ DM for NDF). Our results are entirely consistent with those previously reported for dairy cows grazing at 3 DHA (Peyraud et al., 1996): herbage OM digestibility linearly decreased by $2 \%$ from high to low DHA, with a simultaneous curvilinear decrease in herbage intake $(-4 \%$ between high and medium DHA 
Table 4. Grazing time and herbage intake rate according to energy supplementation (ES; supplemented with 2.6 kg DM barley/d [SUP] and nonsupplemented [NSUP]) level and daily herbage allowance (DHA; low [LOW], medium [MED], and high [HIGH])

\begin{tabular}{|c|c|c|c|c|c|c|c|c|c|c|c|c|}
\hline \multirow[b]{2}{*}{ Item } & \multicolumn{3}{|c|}{ SUP } & \multicolumn{3}{|c|}{ NSUP } & \multirow[b]{2}{*}{ RMSE $^{1}$} & \multicolumn{5}{|c|}{$P$-value } \\
\hline & LOW & MED & HIGH & LOW & MED & HIGH & & ES & DHA & $\mathrm{ES} \times \mathrm{DHA}$ & $\operatorname{Lin}^{2}$ & Quad $^{2}$ \\
\hline \multicolumn{13}{|l|}{ Grazing time } \\
\hline Total, $\mathrm{min} / \mathrm{d}$ & 956 & 1,018 & 1,050 & 965 & 1,028 & 989 & 52.7 & 0.673 & $<0.01$ & 0.115 & $<0.05$ & $<0.05$ \\
\hline First $12 \mathrm{~h},{ }^{3} \mathrm{~min}$ & 661 & 656 & 654 & 631 & 635 & 632 & 12.4 & 0.182 & 0.848 & 0.597 & 0.599 & 0.832 \\
\hline Last $12 \mathrm{~h},{ }^{4} \mathrm{~min}$ & 359 & 438 & 439 & 357 & 397 & 406 & 46.5 & 0.317 & $<0.01$ & 0.508 & $<0.01$ & 0.073 \\
\hline Herbage $\mathrm{IR},{ }^{5} \mathrm{~g}$ DM/min & 11.4 & 11.3 & 12.9 & 11.7 & 12.6 & 14.3 & 1.6 & 0.149 & $<0.01$ & 0.682 & $<0.01$ & 0.249 \\
\hline $\begin{array}{l}{ }^{1} \mathrm{RMSE}=\text { root mean squ } \\
{ }^{2} \mathrm{Lin}=\text { linearity of DHA } \\
{ }^{3} \text { First } 12 \mathrm{~h} \text { in a strip fror } \\
{ }^{4} \mathrm{Last} 12 \mathrm{~h} \text { in a strip fron } \\
{ }^{5} \mathrm{IR}=\text { intake rate. }\end{array}$ & $\begin{array}{l}\text { error. } \\
\text { ect; Qua } \\
915 \text { to } 2 \\
115 \text { to } 0\end{array}$ & $\begin{array}{l}\mathrm{d}=\text { quadr } \\
15 \mathrm{~h} . \\
15 \mathrm{~h} .\end{array}$ & city of DH & effect. & & & & & & & & \\
\hline
\end{tabular}

vs. $-15 \%$ between medium and low DHA). In the present experiment, mares first decreased their intake rate from high to medium DHA $(-12 \%)$ and then their daily grazing time from medium to low DHA $(-6 \%)$. At a low DHA, the mares' grazing activity was mainly reduced during the last hours of their presence on a strip, probably as a result of limiting grazing conditions such as low postgrazing sward height. Here, a reduction in DHA of $50 \%$ decreased pasture intake per mare by $21 \%$ and increased pasture intake per unit area by $54 \%$. This reveals that grazing management designed to maximize individual animal performance is unlikely to maximize pasture utilization rate. Additional studies, therefore, are needed to establish the relationship between herbage allowance, animal intake, and pasture utilization by lactating mares to reach the best equilibrium between individual performance and efficient pasture utilization (Peyraud and Delagarde, 2013).

\section{Energy Supplementation}

Energy supplementation affected neither mares' herbage intake nor their grazing behavior. The substitution rate (i.e., $\mathrm{kg}$ DM reduction in herbage intake $/ \mathrm{kg}$ $\mathrm{DM}$ of concentrate eaten) was, therefore, close to zero $(0.36 \pm 0.12)$, which could be explained by the relatively restricted pasture conditions. Substitution rates have been reported to be higher in dairy cows when DHA is high (Meijs and Hoekstra, 1984; Grainger and Mathews, 1989; Bargo et al., 2002; McEvoy et al., 2008). Literature is scarce on substitution between forages and concentrate in horses. However, substitution has been observed at the trough when horses received forages ad libitum, which may indicate a general trend (Agabriel et al., 1982; Martin-Rosset and Doreau, 1984; Martin-Rosset and Dulphy 1987; Winsco et al., 2013; INRA, 2015). The substitution rate calculated in the present experiment (i.e., 0.36 on average) is, therefore, logically among the lowest values reported for horses fed indoors, which are between 0.3 and 2.4 according to forage type and quality (INRA, 2015). Here, mares receiving barley thus achieved a greater total daily intake (i.e., $+19 \%$ TDDMI and $+24 \%$ NEI) than NSUP mares. Supplemented mares met their energy requirements whatever the DHA, whereas NSUP mares fell short of their requirements at low or medium DHA: 85 and 94\%, respectively, using the INRA system or 82 and $95 \%$, respectively, using the NRC system. From the linear effect of DHA on HDMI, we estimate at $66 \mathrm{~g} \mathrm{DM} \cdot \mathrm{kg} \mathrm{BW}^{-}$ ${ }^{1} \cdot \mathrm{d}^{-1}$ (i.e., $39 \mathrm{~kg} \mathrm{DM} \cdot \mathrm{mare}^{-1} \cdot \mathrm{d}^{-1}$ ) the DHA threshold under which ES is needed for lactating mares to meet their energy requirements on high-quality regrowth (Fig. 2). This DHA threshold corresponds to a postgrazing sward height of $5.4 \mathrm{~cm}$ considering the positive linear relationship between DHA and postgrazing SSH. A postgrazing SSH of $5 \mathrm{~cm}$ could, therefore, be considered a rough reference indicator for this type of pasture and grazing management. However, because postgrazing $\mathrm{SSH}$ is usually linked to the pregrazing SSH under rotational grazing, at least in dairy cows (Pérez-Prieto et al., 2013), it would be worthwhile extending this analysis to a wider range of pregrazing sward structures.

\section{Energy Supplementation $\times$ Daily Herbage Allowance Interaction}

We did not find any effect of the ES $\times$ DHA interaction on herbage intake using an amount of barley representative of what is observed in commercial farms. However, on the high-DHA treatment, mares may have decreased herbage intake if they had received more concentrate. Increasing the proportion of concentrate from 15 to $64 \%$ of TDMI in growing horses fed maize silage offered ad libitum decreased silage intake (Agabriel et al., 1982). Also, in a previous grazing study in which supplemented mares received $2.6 \mathrm{~kg}$ DM barley, their herbage intake was 
(A) Mean of the first $24 \mathrm{~h}$ in a strip

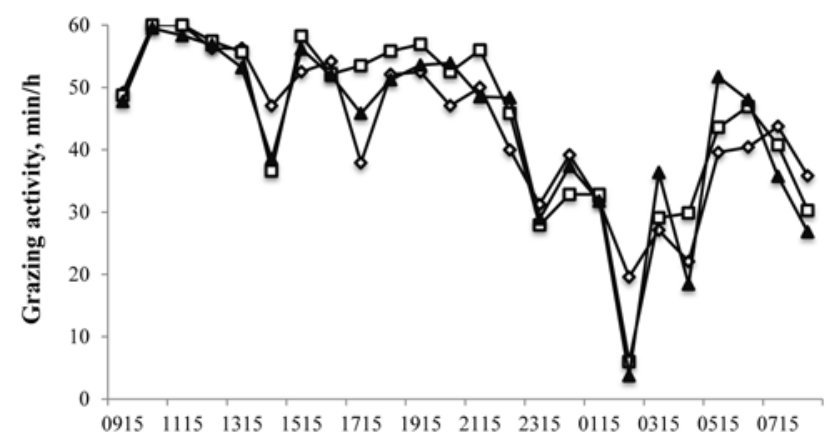

(B) Mean of the last $24 \mathrm{~h}$ in a strip

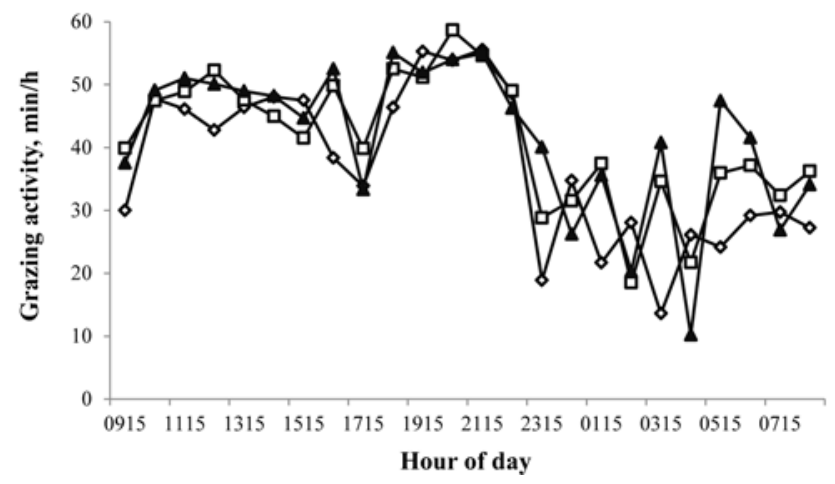

Figure 3. Daily pattern of grazing activity of mares during the $2 \mathrm{~d}$ of grazing in a strip according to daily herbage allowance $(-\infty=$ low, $-\mathbf{0}=$ medium, and $-\mathbf{-}=$ high). (A) Mean of the first $24 \mathrm{~h}$ in a strip and (B) mean of the last $24 \mathrm{~h}$ in a strip (mean grazing time in a strip: low vs. medium, $P<0.05$; low vs. high, $P<0.05$; and medium vs. high, $P>0.05$ ).

significantly lower than that of NSUP mares when DHA was greater than in this study $\left(124 \mathrm{~g} \mathrm{DM} \cdot \mathrm{kg} \mathrm{BW}{ }^{-1} \cdot \mathrm{d}^{-1}\right.$; Collas et al., 2014). These different results suggest possible ES $\times$ DHA interactions outside the range tested in the present experiment, with substitution rate being positively related to DHA as observed in ruminant studies.

\section{Conclusion}

For lactating mares grazing high-quality regrowth during the summer, increasing DHA from 35 to $70 \mathrm{~g}$ $\mathrm{DM} \cdot \mathrm{kg} \mathrm{BW}{ }^{-1} \cdot \mathrm{d}^{-1}$ linearly increased HDMI $(0.13 \mathrm{~kg} \mathrm{DM}$ eaten $/ \mathrm{kg}$ DM of herbage offered), whether or not mares were supplemented with barley. The effects of DHA and ES were additive, so that supplemented mares always met their energy requirements, whereas NSUP mares were underfed at low or medium DHA. The positive linear relationship we established between DHA and HDMI enables us to estimate the herbage allowance threshold (66 $\mathrm{g} \mathrm{DM} \cdot \mathrm{kg} \mathrm{BW}-1 \cdot \mathrm{d}^{-1}$ or $\left.39 \mathrm{~kg} \mathrm{DM} \cdot \mathrm{mare}^{-1} \cdot \mathrm{d}^{-1}\right)$ under which lactating mares should be supplemented with barley to meet their energy requirements. Further investigation of the interactions between concentrate supplementation level, herbage allowance, and herbage nutritive value are needed to improve the efficiency of mare nutrition and maintain a high pasture utilization rate.

\section{LITERATURE CITED}

Agabriel, J., C. Trillaud-Geyl, W. Martin-Rosset, and M. Jussiaux. 1982. Utilisation de l'ensilage de maïs par le poulain de boucherie. (In French.) Bull. Tech. Centre de recherches zootechniques et vétérinaires de Theix, INRA, 49:5-13.

American Horse Council. 2005. National Economic Impact of the U.S. Horse Industry. http://www.horsecouncil.org/nationaleconomic-impact-us-horse-industry. (Accessed 16 June 2014.)

Association Française de Normalisation (AFNOR). 1993. Produits agricoles et alimentaires: Détermination de la cellulose brute, méthode générale. (In French.) Norme Française NF V03-40, octobre 1993, Afnor, Paris, France.

Association Française de Normalisation (AFNOR). 1997. NF V18-120, animal feeding stuffs. Determination of nitrogen content. Combustion method (DUMAS). AFNOR Editions, La Plaine Saint-Denis, France.

Bargo, F., L. D. Muller, J. E. Delahoy, and T. W. Cassidy. 2002. Milk response to concentrate supplementation of high producing dairy cows grazing at two pasture allowances. J. Dairy Sci. 85:1777-1792. doi:10.3168/jds.S0022-0302(02)74252-5.

Collas, C., G. Fleurance, J. Cabaret, W. Martin-Rosset, L. Wimel, J. Cortet, and B. Dumont. 2014. How does the suppression of energy supplementation affect herbage intake, performance and parasitism in lactating saddle mares? Animal 8:12901297. doi:10.1017/S175173111400127X.

Dalley, D. E., J. R. Roche, C. Grainger, and P. J. Moate. 1999. Dry matter intake, nutrient selection and milk production of dairy cows grazing rainfed perennial pastures at different herbage allowances in spring. Aust. J. Exp. Agric. 39:923-931. doi:10.1071/EA99022.

Delaby, L., J. L. Peyraud, and R. Delagarde. 2001. Effect of the level of concentrate supplementation, herbage allowance and milk yield at turn-out on the performance of dairy cows in mid lactation at grazing. Anim. Sci. 73:171-181.

Delagarde, R., P. Faverdin, C. Baratte, and J.-L. Peyraud. 2011. GrazeIn: A model of herbage intake and milk production for grazing dairy cows. 2. Prediction of intake under rotational and continuously stocked grazing management. Grass Forage Sci. 66:45-60. doi:10.1111/j.1365-2494.2010.00770.x.

Delagarde, R., J. L. Peyraud, and L. Delaby. 1999. Influence of carbohydrate or protein supplementation on intake, behaviour and digestion in dairy cows strip-grazing low-nitrogen fertilized perennial ryegrass. Ann. Zootech. 48:81-96. doi:10.1051/animres:19990201.

Doreau, M., S. Boulot, and Y. Chilliard. 1993. Yield and composition of milk from lactating mares - Effect of body condition at foaling. J. Dairy Res. 60:457-466. doi:10.1017/ S0022029900027825.

Doyle, P. T., S. A. Francis, and C. R. Stockdale. 2005. Associative effects between feeds when concentrate supplements are fed to grazing dairy cows: A review of likely impacts on metabolisable energy supply. Aust. J. Agric. Res. 56:1315-1329. doi:10.1071/AR05087.

Duncan, P. 1992. Horses and grasses: The nutritional ecology of equids and their impact on the Camargue. Springer-Verlag, New York, NY.

Edouard, N., P. Duncan, B. Dumont, R. Baumont, and G. Fleurance. 2010. Foraging in a heterogeneous environment - An experimental study of the trade-off between intake rate and diet quality. Appl. Anim. Behav. Sci. 126:27-36. doi:10.1016/j. applanim.2010.05.008. 
Edouard, N., G. Fleurance, B. Dumont, R. Baumont, and P. Duncan. 2009. Does sward height affect feeding patch choice and voluntary intake in horses? Appl. Anim. Behav. Sci. 119:219-228. doi:10.1016/j.applanim.2009.03.017.

European Horse Network. 2010. The European horse industry in the European regions. www.europeanhorsenetwork.eu/horseindustry-in-europe.http://www.europeanhorsenetwork.eu/ the-horse-industry.(Accessed 19 March 2015.)

Goering, H. K., and P. J. Van Soest. 1970. Forage fiber analyses (apparatus, reagents, procedures, and some applications). ARS, Washington, DC.

Grace, N. D., E. K. Gee, E. C. Firth, and H. L. Shaw. 2002a. Digestible energy intake, dry matter digestibility and mineral status of grazing New Zealand thoroughbred yearlings. N. Z. Vet. J. 50:63-69. doi:10.1080/00480169.2002.36252.

Grace, N. D., H. L. Shaw, E. K. Gee, and E. C. Firth. 2002 b. Determination of the digestible energy intake and apparent absorption of macroelements in pasture-fed lactating thoroughbred mares. N. Z. Vet. J. 50:182-185. doi:10.1080/0048 0169.2002.36308.

Grainger, C., and L. Mathews. 1989. Positive relation between substitution rate and pasture allowance for cows receiving concentrates. Aust. J. Exp. Agric. 29:355-360. doi:10.1071/EA9890355.

Henneke, D. R., G. D. Potter, J. L. Kreider, and B. F. Yeates. 1983. Relationship between condition score physical measurements and body fat percentage in mares. Equine Vet. J. 15:371-372. doi:10.1111/j.2042-3306.1983.tb01826.x.

INRA. 2015. Equine nutrition. INRA nutrient requirements, recommended allowances and feed tables. W. Martin-Rosset, editor.

Martin-Rosset, W., and M. Doreau. 1984. Consommation d'aliments et d'eau. In: R. Jarrige and W. Martin-Rosset, editors, Le cheval: Reproduction, sélection, alimentation, exploitation. (In French.) INRA, Paris, France. p. 333-354.

Martin-Rosset, W., and J. P. Dulphy. 1987. Digestibility interactions between forages and concentrates in horses: Influence of feeding level - Comparison with sheep. Livest. Prod. Sci. 17:263-276. doi:10.1016/0301-6226(87)90071-6.

Martin-Rosset, W., J. Vernet, H. Dubroeucq, G. Arnaud, A. Picard, and M. Vermorel. 2008. Variation of fatness and energy content of the body with body condition score in sport horses and its prediction. In: Proc. 4th European Workshop on Equine Nutrition. Nutrition of the Exercising Horse. EAAP publication no. 125. Wageninen Academic Publishers, Wageningen, The Netherlands. p. 167-176.

McEvoy, M., E. Kennedy, J. P. Murphy, T. M. Boland, L. Delaby, and M. O'Donovan. 2008. The effect of herbage allowance and concentrate supplementation on milk production performance and dry matter intake of spring-calving dairy cows in early lactation. J. Dairy Sci. 91:1258-1269. doi:10.3168/jds.2007-0710.

Meijs, J. A. C., and J. A. Hoekstra. 1984. Concentrate supplementation of grazing dairy cows. 1. Effect of concentrate intake and herbage allowance on herbage intake. Grass Forage Sci. 39:59-66. doi:10.1111/j.1365-2494.1984.tb01665.x.

Mésochina, P., W. Martin-Rosset, J. L. Peyraud, P. Duncan, D. Micol, and S. Boulot. 1998. Prediction of the digestibility of the diet of horses: Evaluation of faecal indices. Grass Forage Sci. 53:189-196. doi:10.1046/j.1365-2494.1998.5320189.x.
Mésochina, P., J. L. Peyraud, P. Duncan, D. Micol, and C. TrillaudGeyl. 2000. Ingestion d'herbe au pâturage par le cheval de selle en croissance: Effet de l'âge des poulains et de la biomasse d'herbe. (In French.) Ann. Zootech. 49:505-515. doi:10.1051/animres:2000141.

Micol, D., and W. Martin-Rosset. 1995. Feeding systems for horses on high forage diets in the temperate zone. In: Proc. 4th International Symposium on the Nutrition of Herbivores. Recent Developments in the Nutrition of Herbivores. INRA editions, Versailles, France. p. 569-580.

NRC. 2007. The nutrient requirements of horses, 6th rev. ed. Natl. Acad. Press, Washington, DC.

Penning, P. D. 2004. Animal-based techniques for estimating herbage intake. In: P. D. Penning, editor, Herbage intake handbook. 2nd ed. The British Grassland Society, Reading, UK. p. 53-93.

Pérez-Prieto, L. A., and R. Delagarde. 2013. Meta-analysis of the effect of pasture allowance on pasture intake, milk production, and grazing behavior of dairy cows grazing temperate grasslands. J. Dairy Sci. 96:6671-6689. doi:10.3168/jds.2013-6964.

Pérez-Prieto, L. A., J. L. Peyraud, and R. Delagarde. 2013. Does pre-grazing herbage mass really affect herbage intake and milk production of strip-grazing dairy cows? Grass Forage Sci. 68:93-109. doi:10.1111/j.1365-2494.2012.00876.x.

Peyraud, J. L., E. A. Comeron, M. H. Wade, and G. Lemaire. 1996. The effect of daily herbage allowance, herbage mass and animal factors upon herbage intake by grazing dairy cows. Ann. Zootech. 45:201-217. doi:10.1051/animres:19960301.

Peyraud, J. L., and L. Delaby. 2001. Ideal concentrate feeds for grazing dairy cows - Responses to supplementation in interaction with grazing management and grass quality. In: P. C. Garnsworthy and J. Wiseman, editors, Recent advances in animal nutrition. Nottingham Univ. Press, Nottingham, UK. p. 203-220.

Peyraud, J. L., and R. Delagarde. 2013. Managing variations in dairy cow nutrient supply under grazing. Animal 7:57-67. doi:10.1017/S1751731111002394.

Scheibe, K. M., T. Schleusner, A. Berger, K. Eichhorn, J. Langbein, L. Dal Zotto, and W. J. Streich. 1998. ETHOSYS ${ }^{\circledR}-$ New system for recording and analysis of behavior of free-ranging domestic animals and wildlife. Appl. Anim. Behav. Sci. 55:195-211. doi:10.1016/S0168-1591(97)00072-5.

Stockdale, C. R. 2000. Levels of pasture substitution when concentrates are fed to grazing dairy cows in northern Victoria. Aust. J. Exp. Agric. 40:913-921. doi:10.1071/EA00034.

Trillaud-Geyl, C., J. Brohier, L. de Baynast, N. Baudoin, E. Rossier, and O. Lapierre. 1990. Bilan de productivité sur 10 ans d'un troupeau de juments de selle conduites en plein air intégral: Croissance des produits de 0 à 6 mois. (In French.) World Rev. Anim. Prod. 25:65-70.

Wales, W. J., P. T. Doyle, and W. Dellow. 1998. Dry matter intake and nutrient selection by lactating cows grazing irrigate pastures at different pasture allowances in summer and autumn. Aust. J. Exp. Agric. 38:451-460. doi:10.1071/EA98043..

Winsco, K. N., J. A. Coverdale, T. A. Wickersham, J. L. Lucia, and C. J. Hammer. 2013. Influence of maternal plane of nutrition on mares and their foals: Determination of mare performance and voluntary dry matter intake during late pregnancy using a dual-marker system. J. Anim. Sci. 91:4208-4215. doi:10.2527/jas.2013-6373. 